\title{
ANALISIS KESULITAN MEMBACA PADA SISWA KELAS V SDI WAIROTANG
}

\author{
Sonya Kristiani Maria \\ Universitas Nusa Nipa, Maumere
}

\begin{abstract}
The purpose of this study was to describe the reading difficulties experienced by the fifth grade students of SDI Wairotang and to determine the factors that hindered students from reading difficulties. This study uses a qualitative approach with descriptive qualitative research methods. The data sources in this study were teachers and students of SDI Wairotang who have difficulty reading. Data collection techniques using interview and documentation techniques. Data analysis techniques used Miles and Huberman, namely reducing data, presenting data and drawing conclusions. The results showed that the difficulties experienced by students were not fluent in reading, spelling, and inappropriate use of punctuation marks and factors that prevented students from reading, namely the lack of interest in learning to read and the lack of family support in learning to read. Based on the results of the research conducted, it can be concluded that the difficulties of students in reading and inhibiting factors in reading in class V SDI Wairotang are: not yet fluent in reading, spelling and inappropriate use of punctuation and lack of interest in learning to read and lack of family support in learning read.
\end{abstract}

Keyword: analysis, difficulty, reading

Abstrak

Tujuan dari penelitian ini adalah untuk mendeskripsikan kesulitan membaca yang di alami siswa kelas V SDI Wairotang dan untuk mengetahui faktor-faktor yang menghambat siswa dalam kesulitan membaca. Penelitian ini menggunakan pendekatan kualitatif dengan jenis metode penelitian deskriptif kualitatif. Sumber data dalam penelitian ini adalah guru dan siswa SDI Wairotang yang berkesulitan membaca. Teknik pengumpulan data menggunakan teknik wawancara dan dokumentasi. Teknik analisis data menggunakan Miles and Huberman yaitu mereduksi data, menyajikan data dan penarikan kesimpulan. Hasil penelitian yang menunjukkan kesulitan yang dialami siswa adalah membaca belum lancar, mengeja, dan 
penggunaan tanda baca kurang tepat dan faktor-faktor yang menghambat siswa dalam membaca yakni kurangnya minat belajar membaca serta kurangnya dukungan keluarga dalam belajar membaca. Berdasarkan hasil penelitian yang dilakukan maka dapat disimpulan bahwa kesulitan-kesulitan siswa dalam membaca dan faktor penghambat dalam membaca di kelas $\mathrm{V}$ SDI Wairotang yaitu: belum lancar membaca, mengeja dan penggunaan tanda baca yang kurang tepat serta kurangnya minat belajar membaca dan kurangnya dukungan keluarga dalam belajar membaca.

Kata Kunci : analisis, kesulitan, membaca

\section{PENDAHULUAN}

Bahasa Indonesia merupakan salah satu mata pelajaran yang penting di sekolah dasar. Mata pelajaran ini diadakan agar anak mampu mengkomunikasikan bahasa negaranya dengan baik dan benar secara lisan maupun tulisan. Bahasa Indonesia sangat penting bagi kehidupan berbangsa dan bernegara maka harus dipelajari melalui jalur pendidikan di sekolah. ${ }^{1}$ Pembelajaran Bahasa Indonesia di sekolah, mengembangkan empat keterampilan berbahasa, yakni membaca, menulis, berbicara dan menyimak. Salah satu keterampilan berbahasa yang harus dikuasai siswa adalah membaca. Dengan membaca, siswa akan lebih mengenal dunia dan dengan banyak membaca pula siswa dapat mengembangkan keterampilan-keterampilan berbahasa lainnya.

Membaca pada hakikatnya adalah suatu yang rumit yang melibatkan banyak hal tidak hanya sekedar melafalkan tulisan, tetapi juga melibatkan aktivitas visual, berpikir, psikolinguistik, dan metakognitif. Sebagai proses visual membaca merupakan proses menerjemahkan simbol tulis (huruf) ke dalam kata-kata lisan. Membaca adalah proses yang kompleks Membaca merupakan akivitas pemrosesan kata-kata, konsep, informasi, dan gagasan-gagasan yang dikemukankan oleh pengarang yang berhubungan dengan pengetahuan dan pengalaman awal pembaca dengan mengamati simbol-simbol

\footnotetext{
11.

${ }^{1}$ Resmini dkk., Ejaan bahasa Indonesia, (Bandung: Angkasa, 2009),
} 
tulisan, menghubungkan kata-kata, membuat referensi dan evaluasi, dan menginterpretasikan apa yang diamati. ${ }^{2}$

Membaca adalah suatu proses yang dilakukan serta dipergunakan oleh pembaca untuk memperoleh pesan yang hendak disampaikan oleh penulis melalui media kata-kata atau bahasa tulis. ${ }^{3}$ Membaca juga dapat didefinisikan sebagai suatu proses menuntun agar kelompok kata yang merupakan suatu kesatuan akan terlihat dalam suatu pandangan sekilas dan agar makna kata-kata secara individu akan dapat diketahui. Membaca semakin penting karena setiap aspek kehidupan melibatkan kegiatan membaca. Misalnya: adanya tanda-tanda jalan yang dapat mengarahkan orang yang bepergian sampai pada tujuannya, judul buku dan koran diterbikan setiap harinya sehingga orang dapat menerima informasi yang disampaikan.

Dunia pendidikan erat kaitannnya dengan kegiatan pembelajaran. Pembelajaran adalah upaya membelajarkan siswa untuk belajar. Proses pembelajaran, sebagai proses implementasi kurikulum, menuntut peran guru untuk mengartikulasikan kurikulum atau bahan pelajaran serta mengembangkan dan mengimplementasikan program-program pembelajaran dalam suatu tindakan yang akurat. ${ }^{4}$ Berdasarkan pendapat tersebut dapat dikatakan pembelajaran sebagai suatu upaya menciptakan kondisi yang memungkinkan siswa dapat belajar, secara menyeluruh terlihat bahwa ada kegiatan memilih, menetapkan dan mengembangkan metode untuk mencapai tujuan yang diinginkan.

Pembelajaran membaca sampai saat ini masih dinilai sangat penting di sekolah. Hal ini disebabkan oleh kenyataan bahwa pembelajaran membaca tidak hanya berperan dalam meningkatkan kemampuan berbahasa siswa, namun lebih jauh memberikan manfaat bagi peningkatan kemampuan siswa. Pembelajaran membaca sangat penting bagi siswa, karena kemampuan membaca berkaitan dengan proses memahami dan

\footnotetext{
${ }^{2}$ Nuhardi, Kiat-kiat membaca. (Jakarta: Alfabeta, 2015), 23.

3 Taringan dkk., Membaca sebagai suatu keterampilan berbahasa. (Bandung: Angkasa, 2018),,37.

4 Januarti dkk., "Analisis Kesulitan Belajar Dalam Pembelajaran Membaca Cepat Siswa Kelas V SD Gugus VI Kecamatan Abang”.dalam Jurnal Andragogik Vol. 4 No. 1.
} 
memberikan makna, memanfaatkan dengan tepat bahan bacaan yang dibaca untuk meningkatkan pengetahuan dan wawasan sehingga memiliki kemampuan lebih dari orang lain.

Kesulitan belajar merupakan persoalan yang umum dan lumrah terjadi pada peserta didik dalam akademisinya. Meskipun begitu masalah kesulitan belajar pada peserta didik tidak boleh dipandang remeh. Masalah tersebut hendaknya sesegera mungkin dilakukan tindakan atau penanganan khusus, agar anak didik mampu berhasil menyelesaikan studinya di sekolah. Pelayanan yang diberikan bagi anak berkesulitan belajar, berorientasi pada kebutuhan individual yang diperlukan untuk keberhasilan belajar secara optimal berdasarkan kapasiatas yang dimilikinya. Kesulitan belajar sebagai suatu gejala yang nampak pada peserta didik yang ditandai dengan adanya hasil belajar yang rendah atau di bawah norma yang telah ditetapkan. ${ }^{5}$

Hal ini didasarkan pada heterogenitas kesulitan belajar yang dialamai oleh peserta didik di sekolah, mengingat kesulitan belajar itu sendiri sangat bervariasi jenisnya. Secara garis besar kesulitan belajar anak dapat diklasifikasikan ke dalam dua kelompok; pertama kesulitan belajar yang berhubungan dengan perkembangan (developmental learning disabilities) dan kedua kesulitan belajar akademik (academic learning disabilities.)

Berdasarkan observasi awal yang dilakukan oleh peneliti di SDI Wairotang dapat diketahui bahwa pada prosesnya dalam menguasai kemampuan membaca, $60 \%$ siswa mengalami kesulitan. Untuk masalah-masalah seperti kesulitan membaca pada siswa ini seringkali kurang mendapat perhatian dari guru dan juga orang tua. Pendidik atau guru yang setiap harinya berkecimpung dalam proses pendidikan, cenderung belum memahami benar siswa yang mengalami kesulitan belajar. Siswa akan berkembang secara optimal melalui perhatian guru yang positif, begitupun sebaliknya. Orang tua yang tidak mendukung anak dalam proses belajar akan menjadi pengaruh

5 Sugihartono, Cara Mengatasi Kesulitan Membaca Pada Anak. (Jakarta: Alfabeta, 2007), 32. 
terhadap hasil belajar anak sehingga prestasi belajar anak pun menurun.

Faktor-faktor penyebab kesulitan membaca yang dialami oleh setiap anak dapat disebabkan oleh faktor internal pada diri anak itu sendiri atau faktor ekternal di luar diri anak. Faktor internal pada diri anak meliputi faktor fisik, intelektual dan psikologis. Adapun faktor eksternal di luar diri anak mencakup lingkungan keluarga dan sekolah. Kesulitan yang dialami oleh masing-masing siswa berbeda antara yang satu dengan yang lainnya. Dalam kondisi tersebut guru perlu mengupayakan bantuan dan pendampingan agar anak yang mengalami kesulitan membaca tersebut segera mendapatkan penanganan yang tepat.

Penelitian kualitatif adalah penelitian yang bermaksud untuk memahami fenomena tentang apa yang dialami oleh subjek penelitian misalnya perilaku, perepsi, motivasi dan tindakan secara holistic dengan cara deskripsi dalam bentuk kata-kata. ${ }^{6}$ Dalam melakukan penelitian dibutuhkan pendekatan untuk menjawab permasalahan yang sedang diteliti sehingga dapat dibuktikan kebenaran dari data-data yang diperoleh. Dalam hal ini peneliti menggunakan metode kualitatif. Penelitian kualitatif adalah jenis penelitian yang mengutamakan masalah kualitas (mutu) dari objek yang diteliti, bukan kuantitasnya (besaran jumlah). Karena mengutamkan mutu, maka penelitian jenis ini cenderung mengarah pada aspek psiko-sosiologis dibandingkan besaran hitungan pasti dari objek yang diteliti.

Penelitian kualitatif juga disebut dengan metode penelitian naturalistik, karena penelitiannya dilakukan pada kondisi yang alamiah (natural setting). Menurut Bogdan dan Taylor, metodologi kualitatif adalah prosedur penelitian yang menghasilkan data deskriptif kualitatif yang berupa kata-kata tertulis atau lisan dari orang-orang dan perilaku yang diamati. Penelitian kualitatif bertujuan untuk mendapatkan pemahaman yang sifatnya umum terhadap kenyataan sosial dari perspektif partisipan. Pemahaman tersebut tidak ditentukan terlebih

${ }^{6}$ Moleong. 2016. Metodologi Penelitian kualitatif. Jakarta: Remaja Rosdakarya. 
dahulu akan tetapi didapat setelah melakukan analisis terhadap kenyataan sosial yang menjadi fokus penelitian. Berdasarkan analisis tersebut, kemudian ditarik kesimpulan berupa pemahaman umum yang sifatnya abstrak tentang kenyataankenyataan.

\section{PEMBAHASAN}

Peneliti menyajikan hasil penelitian yang berhubungan dengan Analisis Kesulitan Membaca Pada Siswa Kelas V SDI Wairotang, dengan fokus kajian yang diuraikan sesuai sebagai berikut:

Jenis Kesulitan Membaca

a. Kesulitan Membaca Belum Lancar

Berdasarkan hasil wawancara dengan responden, peneliti menemukan bahwa siswa belum lancar membaca. Hal ini dibuktikan dengan hasil wawancara terhadap $\mathrm{K} \mathrm{L}$ wali kelas V A pada Jumad 19 Juni 2020 yang menyatakan bahwa : "Yang saya amati itu ada beberapa kesulitan seperti membaca kurang lancar, mengeja dan penggunaan tanda baca yang kurang tepat. Yang pertama itu menurut saya kesulitan yang dialami oleh siswa dalam membaca kurang lancar beberapa siswa membaca". Lalu pernyataan yang sama juga diungkapkan oleh YW wali kelas V B pada Sabtu, 20 Juni 2020 mengatakan bahwa : "Kalau saya kesulitan siswa dalam membaca yang saya amati di kelas itu pertama membaca kurang lancar, mereka membaca masih sendat-sendat"

b. Kesulitan Membaca Masih Mengeja

Berdasarkan hasil wawancara dengan responden, peneliti menemukan bahwa siswa membaca masih mengeja. Hal ini dibuktikan dengan hasil wawancara terhadap KL wali kelas V A pada Jumad, 19 Juni 2020 yang menyatakan bahwa: "menurut saya mereka sudah bagus membaca namun ada beberapa yang masih mengeja" Lalu pernyataan yang sama juga diungkapkan oleh YW wali kelas V B pada Sabtu, 20 Juni 2020 mengatakan bahwa: "kedua ada beberapa siswa yang bacanya masih mengeja, kami guru harus menuntun mereka agar bisa baca dengan lancar".

c. Kesulitan Membaca Penggunaan Tanda Baca Kurang Tepat 
Berdasarkan hasil wawancara dengan responden, peneliti menemukan bahwa siswa belum tetap dalam menggunakan tanda baca. Hal ini dibuktikan dengan hasil wawancara terhadap KL wali kelas V A pada Jumad, 19 Juni 2020 yang menyatakan bahwa: "Yang ketiga menurut saya beberapa siswa di kelas saya itu mereka sudah bagus dalam membaca namun penggunaan tanda baca ini yang kadang mereka masih salah meletakannya. Contohnya tanda baca titik sereingkali mereka melakukan pemenggalan atau berhenti membaca"

Lalu pernyataan yang sama juga diungkapkan oleh YW wali kelas V B pada Sabtu, 20 Juni 2020 mengatakan bahwa: "yang terakhir itu penggunaan tanda baca yang salah. Yang saya amati dalam kelas siswa-siswi saya banyak yang sudah bagus dalam membaca. Tetapi mereka tidak memperhatikan tanda baca dengan baik. Mereka seringkali pemenggalan pada tempatyang tidak tepat khususnya tanda koma"”.

Jadi dapat disimpulkan bahwa kemampuan siswa yang masih kesulitan membaca di SDI Wairotang khususnya kelas V sangat majemuk mulai dari siswa kurang lancar membaca, mengeja dan penggunaan tanda baca kurang tepat.

Faktor Yang Mempengaruhi Siswa Yang Berkesulitan Membaca

a. Kurangnya Minat Belajar siswa

Berdasarkan hasil wawancara yang dilakukan kepada responden, mengenai faktor kesulitan belajar seperti yang diungkapkan oleh ibu KL wali kelas V A pada Jumad, 19 Juni 2020 sebagai betikut: "Menurut saya faktor kesulitan belajar ini yang pertama kurangnya minat belajar siswa sehingga kemampuan membacanya menurun tidak sama dengan siswa yang membacanya cepat.

b. Lalu pernyataan yang sama juga diungkapkan oleh YW wali kelas V B kepada peneliti pada Sabtu, 20 Juni 2020 menyatakan bahwa: "Menurut saya yang pertama kurangnya minat belajar siswa sehingga kemampuan membaca siswa tersebut kurang bagus".

${ }^{7}$ Wawancara dengan Wali kelas V A di SDI Wairotang pada Tanggal 19 Juni 2020 
c. Kurangnya Dukungan Dari Keluarga

Berdasarkan hasil wawancara yang dilakukan kepada responden, mengenai faktor kesulitan belajar seperti yang diungkapkan oleh ibu KL wali kelas V A pada Jumad, 19 Juni 2020 sebagai betikut: "yang kedua menurut saya kurangnya dukungan dari keluarga, pada saat pulang sekolah ada beberapa orang tua menyuruh anaknya untuk pergi jualan sayur ikut dengan mamanya sehingga tidak ada waktu untuk siswa belajar membaca di rumah". Lalu pernyataan yang sama juga diungkapkan oleh YW wali kelas V B kepada peneliti pada Sabtu, 20 Juni 2020 menyatakan bahwa: "Yang saya amati, faktor kesulitan belajar siswa yang kedua kurangnya dukungan dari keluarga. Ada beberapa siswa yang berasal dari keluarga yang kurang mampu ${ }^{8 "}$.

Dari pernyataan diatas dapat disimpulkan bahwa faktor utama yang menyebabkan siswa kesulitan membaca dibagi atas dua yakni faktor internal dan faktor eksternal. Faktor internal yakni kurangnya minat membaca dari siswa sendiri, motivasi/ minat dari dalam diri siswa menjadi faktor utama sebab kesadaran dari dalam diri akan mendorong siswa untuk tetap belajar apapun halangan yang ada di hadapannya, sedangkan faktor eksternal lebih kepada keluarga tempat ia tumbuh yang kurang memperhatikan kekurangan yang ia miliki (kurangnya dukungan keluarga)

Hasil Wawancara dengan Siswa Kelas $V A$ dan Siswa Kelas $V$ B SD SDI Wairotang

a. Siswa Kelas V A

Berdasarkan hasil wawancara yang dilakukan terhadap siswa kelas V A SDI Wairotang, berikut data dari 12 siswa kelas $\mathrm{V}$ yang mengalami kesulitan membaca dan 3 orang siswa yang diwawancarai peneliti sebagai berikut :

1) Kesulitan membaca pada siswa kelas $V$ A bernama $R O$

Kesulitan yang dialami oleh RO dalam membaca yaitu belum lancar membaca dan membaca masih mengeja. Wawancara yang dilakukan terhadap RO pada Sabtu, 20 Juni 2020, menghasilkan deskripsi tentang faktor penghambat dalam

${ }^{8}$ Wawancara dengan Wali kelas V A di SDI Wairotang pada Tanggal 20 Juni 2020 
membaca yaitu kurangnya minat belajar. Pembelajaran yang dilakukan sesekali oleh RO di rumah yaitu membaca teks bacaan pada buku yang di berikan ibu guru dan di temani oleh ibu atau kakak.

2) Kesulitan membaca pada siswa kelas V A Bernama NF

Kesulitan yang dialami oleh NF dalam membaca yaitu penggunaan tanda baca yang kurang tepat. Wawancara yang dilakukan terhadap NF pada Senin, 22 Juni 2020 menghasilkan deskripsi tentang faktor penghambat dalam membaca yaitu kurangnya minat belajar. Pembelajaran yang dilakukan oleh NF di rumah yaitu membaca teks bacaan pada buku yang diberikan ibu guru dan pada buku tematik siswa dan di temani ibu.

3) Kesulitan membaca pada siswa kelas V A Bernama KV

Kesulitan yang dialami oleh KV dalam membaca yaitu membaca masih mengeja. Wawancara yang dilakukan terhadap KV pada Selasa, 23 Juni 2020 menghasilkan deskripsi tentang faktor penghambat dalam membaca yaitu kurangnya minat belajar. Pembelajaran yang dilakukan oleh KV di rumah yaitu membaca teks bacaan pada buku yang diberikan ibu guru dan pada buku tematik siswa dan di temani orang tua9.

b. Siswa Kelas V B

Berdasarkan hasil wawancara yang dilakukan terhadap siswa kelas V B SDI Wairotang, berikut data dari 9 siswa kelas $\mathrm{V}$ yang mengalami kesulitan membaca dan 3 orang yang diwawancarai peneliti sebagai berikut :

1) Kesulitan membaca pada Siswa kelas V B bernama BW

Kesulitan membaca yang dialami oleh BW yaitu, membaca masih mengeja dan penggunaan tanda baca kurang tepat. Wawancara yang dilakukan terhadap BW pada Rabu, 24 Juni 2020 menghasilkan deskripsi tentang faktor penghambat dalam membaca yaitu kurangnya minat belajar. Pembelajaran yang dilakukan sesekali oleh BW di rumah yaitu membaca teks bacaan pada buku tematik dan di temani oleh orang tua.

2) Kesulitan membaca pada Siswa kelas V B bernama AL

Kesulitan membaca yang dialami oleh AL yaitu penggunaan tanda baca yang kurang tepat. Wawancara yang

9 Wawancara dengan Siawa Kelas V A di SDI Wairotang pada Tanggal 20-23 Juni 2020 
dilakukan terhadap AL pada Kamis, 25 Juni 2020 menghasilkan deskripsi tentang faktor penghambat dalam membaca yaitu kurangnya minat belajar. Pembelajaran yang dilakukan sesekali oleh AL di rumah yaitu membaca teks bacaan pada buku tematik dan di temani oleh ibunya.

3) Kesulitan membaca pada Siswa kelas V B bernama VD

Kesulitan membaca yang dialami oleh VD yaitu belum lancar membaca dan mengeja. Wawancara yang dilakukan terhadap VD pada Jumad, 26 Juni 2020 menghasilkan deskripsi tentang faktor penghambat dalam membaca yaitu kurangnya minat belajar. Pembelajaran yang dilakukan sesekali oleh VD di rumah yaitu membaca teks bacaan pada buku tematik dan di temani oleh orang tua ${ }^{10}$.

Dari pernyataan diatas dapat disimpulkan bahw para siswa pada dasarnya membutuhkan bantuan dari orang tua atau keluarga dalam upaya membaca, orang tua selalu mendampingi anak-anak mereka dan memperbaiki jika ada kesalahan berkenaan membaca kurang lancar, ejaan maupun tanda baca.

Kesulitan-Kesulitan Membaca Pada Siswa Kelas V

\section{1) Belum Lancar Membaca}

Belum lancar membaca merupakan keadaan dimana seorang tidak mampu membaca suatu kalimat atau paragraph atau sebuah tulisan secara lancar tanpa hambatan atau sendatsendat dan sesuai dengan tempo yang tepat atau tidak terlalu cepat dan tidak terlalu lambat. Beberapa siswa kelas V SDI Wairotang belum mampu membaca dengan lancar karena kegiatan membaca tidak dilakukan secara teratur dan kurangnya minat belajar siswa. Kesulitan membaca dapat didefinisikan sebagai suatu gejala kesulitan dalam mempelajari komponen-komponen dalam kalimat ${ }^{11}$. Ada banyak hal yang menjadi latar belakang penyebab seseorang tidak mampu membaca dengan lancar, selain karena motivasi yang masih rendah juga bisa disebabkan faktor fisiologis, ini berkaitan dengan kesehatan fisik, seorang anak yang mengalami

\footnotetext{
${ }^{10}$ Wawancara dengan Wali kelas V B di SDI Wairotang pada Tanggal 24-26 Juni 2020

11 Abdurrahman. 2009. Pendidikan bagi anak berkesulitan belajar. Jakarta: Depdikbud \& Rineka Cipta.
} 
gangguan pada alat bicara atau alat pengelihatan. Di luar dari pada itu, untuk meningkatkan kemampuan membaca seorang anak agar ia mampu membaca dengan lancar adalah dengan meningkatkan pengawasan terhadap anak tersebut agar didikan lebih berpusat pada mereka yang masih kurang lancar membaca agar kemampuan mereka dapat berkembang.

Kesulitan belajar membaca merupakan suatu sindrom kesulitan dalam mempelajari komponen-komponen kata dan kalimat, mengintegrasikan komponen kata-kata dan kalimat, dan dalam belajar segala sesuatu yang berkenaan dengan waktu, arah, dan masa ${ }^{12}$. Kesulitan membaca merupakan suatu keadaan individu yang memiliki kemampuan membaca rendah berdasarkan rerata kemampuan yang telah ditetapkan ${ }^{13}$. Kesulitan membaca merupakan suatu keadaan ketika siswa tidak mampu mengidentifikasi kata sehingga siswa memiliki kecepatan membaca yang lambat dan memiliki pemahaman bacaan yang rendah ${ }^{14}$.

Kesulitan membaca ini mengakibatkan kemampuan siswa dalam berbagai mata pelajaran sehingga nilai siswa rendah. Kesalahan dalam membaca seperti kata dulu menjadi duku, yang akhirnya membuat sebuah kesalahan dalam memahami soal dan diakhiri dengan salah dalam menjawab.

2) Mengeja

Mengeja merupakan melafalkan atau menyebutkan satu demi satu huruf untuk membentuk suatu kata atau kalimat. Dari hasil penelitian empat dari enam siswa kelas V SDI Wairotang masih mengeja dalam membaca. Siswa tidak mampu membaca membaca dengan lancar tetapi masih mengeja huruf demi huruf. Seharusnya pada tingkatan kelas tinggi seperti siswa harus sudah memiliki kemampuan membaca dengan lancar, namun pada kenyataannya belum semua siswa telah memiliki kemampuan membaca dengan lancar, masih ada beberapa yang belum lancar dalam membaca yang ditandai

12 Abdurrahman. 2009. Pendidikan bagi anak berkesulitan belajar. Jakarta: Depdikbud \& Rineka Cipta.

13 Abidin. 2010. Strategi membaca teori dan dan pembelajarannya. Bandung: Risqi press.

${ }^{14}$ Snowing. 2013. Early Identification and Interventions for Dyslexia: A 
dengan membaca masih mengeja. Ini menyebabkan proses pembelajaran di kelas menjadi terhambat, sehingga peran guru harus ditingkatkan sekaligus mendorong siswa yang masih belum lancar tersebut untuk tekun daalam melatih dirinya sendiri di sekolah dan di rumah.

Mengeja merupakan suatu kegiatan dalam menyusun serangkaian huruf menjadi suatu kata yang berarti ${ }^{15}$. Ejaan adalah keseluruhan peraturan bagaimana menggambarkan bagaimana bunyi-bunyian dan bagiamana interelasi antara lambang-lambang itu (pemisahanya, penggambunganya) dalam suatu bahasa ${ }^{16}$. Dalam proses perkembangan membaca, tentu saja tiap siswa akan melewati tahap mengeja, setelah melewati tahap ini, seorang anak akan mampu membaca suatu suatu kata maupun kalimat secara langsung tanpa mengejan huruf demi huruf. Tahap ini merupakan tahap penting katika seorang anak diperkenalkan dengan huruf demi huruf dan merangkainya menjadi sebuah kata. Namun akan menjadi masalah ketika seorang anak yang berada di keas tinggi yang seharusnya sudah mampu membaca lancar tanpa mengeja justru belum mampu melakukannya.

Kesulitan membaca seperti ini tentu menjadi masalah yang cukup serius, sebab sebagaiamana telah disinggung sebelumnya bahwa siswa yang masih kesulitan membaca atau membaca dengan mengeja tertinggal cukup jauh. Pada posisi ini tentu saja anak tersebut harus diberikan pendampingan yang lebih intensif, agar kemampuan membacanya sesuai dengan jenjang pendidikannya.

3) Penggunaan Tanda Baca Kurang Tepat

Kesulitan membaca dengan penggunaan tanda baca kurang tepat. Beberapa siswa kelas V SDI Wairotang seringkali melakukan pemenggalan (berhenti membaca) pada tempat yang tidak tepat atau tidak memperhatikan tanda baca, khususnya tanda koma. Tanda baca atau pungtuasi adalah gambar-gambar atau tanda-tanda yang secara konvensional disetujui seccara bersama untuk memberikan kunci kepada pembaca terhadap apa yang ingin disampaikan kepada mereka. Lebih jauh lagi ia

\footnotetext{
${ }^{15}$ Zuhri. 2016. Mengeja Tulisan. Bandung: Angkasa

${ }^{16}$ Keraf. 1984. Cara Membaca yang Baik. Jakarta: Alfabeta
} 
menjelaskan bahwa tanda baca dipergunakan untuk menehelaskan maksud penulis agar informasi yang disampaikan tidak salah diterima oleh pembaca. Tanda baca berupa titik, koma, tanda petik satu, tanda petik dua, titik koma, titik dua, tanda Tanya, tanda seru, dan sebagaianya.

Dalam sebuah kalimat, terdapat berbagai macam tanda baca yang berfungsi mengatur jeda ketika membaca, mengatur intonasi dalam membaca sebuah kalimat, maupun member penegasan kalimat, (kalimat perintah atau kalimat tanya). Beberapa siswa seringkali melakukan pemenggalan (berhenti membaca) pada tempat yang tidak tepat atau tidak memperhatikan tanda baca, khususnya tanda koma. Kesulitan membaca ini lebih berkaitan dengan hal teknis yang terjadi bukan hanya pada siswa-siswi sekolah dasar saja, tetapi juga pada jenjang yang lebih tinggi. Usaha yang perlu dilakukan untuk mengatasinya adalah dengan latihan membaca terus menerus; memahami penggunaan tanda baca dan bagaimana menggunakan kalimat dan cara melafalkannya dengan benar.

Kesulitan belajar membaca disebabkan oleh perkembangan syaraf pusat yang mengalami disfungsi minimal ${ }^{17}$. Kesulitan belajar membaca merupakan suatu sindrom kesulitan dalam mempelajari komponen-komponen kata dan kalimat, mengintegrasikan komponen kata-kata dan kalimat, dan dalam belajar segala sesuatu yang berkenaan dengan waktu, arah, dan masa ${ }^{18}$.

Kesulitan membaca ini mengakibatkan kemampuan siswa dalam berbagai mata pelajaran sehingga nilai siswa rendah. Kesalahan dalam membaca seperti kata dulu menjadi duku, yang akhirnya membuat sebuah kesalahan dalam memahami soal dan diakhiri dengan salah dalam menjawab.

Kurangnya minat belajar membaca

Pada hakikatnya siswa kelas V SDI Wairotang lebih menyukai belajar sambil bermain, kurang konsentrasi pada guru yang mengajar di depan kelas, sehingga pihak sekolah terutama

\footnotetext{
17 Jamaris dan Martini. 2009. Kesulitan Belajar, prespektif assesmen dan penanggulangannya. Jakarta: Yayasan Pena Mas Murni.

18 Abdurrahman. 2009. Pendidikan bagi anak berkesulitan belajar. Jakarta: Depdikbud \& Rineka Cipta.
} 
guru harus bisa menciptakan suasana kegiatan belajar mengajar yang menyenangkan untuk belajar membaca dan meyediakan berbagai media yang tepat untuk membantu anak dalam membaca. Di SDI Wairotang dan media yang digunakan belum cocok, sehingga anak kurang tertarik dalam membaca dan anak akan merasa jenuh.

Kurangnya Dukungan Keluarga dalam Belajar Membaca.

Keluarga adalah faktor pendukung utama dalam keberhasilan anak dalam membaca, terutama orang tua yang merupakan guru pertama anak. Dalam hal ini banyak orang tua yang member perhatian terhadap anaknya secara maksimal karena banyak orang tua yang sibuk bekerja, menyerahkan tanggung jawab sepenuhnya ke pihak sekolah dan juga pendidikan pendidikan orang tua yang masih rendah. Sehingga pembelajaran membaca yang di peroleh anak di rumah kurang maksimal.

Selain itu faktor-faktor yang menyebabkan anak mengalami kesulitan belajar membaca adalah a) Minat baca. Minat baca adalah suatu hal timbul secara sadar dalam diri seorang anak, maka dari itu minat perlu dikembangkan oleh orang tua atau guru akan dapat membawa kebaikan pada anak; b) Motivasi. Kegiatan belajar mengajar didalam kelas akan berjalan dengan lancar apabila diri siswa terdapat motivasi yang besar sehingga dapat mencapai tujuan dalam belajar; dan c) Kepemilikan minat membaca. Keterampilan berbahasa ada 4 yaitu membaca, berbicara, menyimak dan menulis. Semuanya harus dilakukan secara teratur agar keterampilan membaca dapat dimiliki oleh siswa dengan baik.

Dalam hal ini adalah bagaimana lingkungan mendukung siswa agar mencintai kegiatan membaca. Hal ini dapat diwujudkan dengan adanya fasilitas perpustakaan yang bersih dan memadai, sehingga siswa senang untuk melakukan aktifitas membaca didalam perpustakaan sekolah.

Dari beberapa hasil penelitian yang telah dilakukan, saran yang perlu dilakukan adalah (a) guru harus memperhatikan satu persatu siswa yang belum mampu membaca. Guru dapat memberikan tambahan waktu belajar, atau ketika di kelas siswa yang tidak dapat membaca agar siswa tersebut dapat menjadi guru sebaya bagi siswa tersebut. (b) penggunaan metode yang bervariasi sangat diperlukan saat 
pembelajaran agar tidak memudahkan memunculkan rasa bosan. Selain itu juga, guru bisa menggunakan media yang lebih menarik agar dapat memunculkan rasa semangat siswa untuk belajar. Adapu saran untuk orang tua adalah sebaiknya meluangkan waktu untuk mendampingi anak saat belajar di rumah. Memberikan dorongan, motivasi dan semangat tidak hanya sekedar melalui ucapan tetapi juga melalui tindakan. Belajar bersama menjadi salah satu cara untuk menjalin kedekatan emosi juga antara orang tua dan anak.

\section{PENUTUP}

Berdasarkan hasil penelitian yang dilakukan peneliti di SDI Wairotang maka dapat disimpulkan bahwa kesulitankesulitan siswa dalam membaca di kelas V SDI Wairotang yaitu: Belum lancar membaca, mengeja dan penggunaan tanda baca yang kurang tepat. Faktor-faktor yang menghambat siswa dalam kesulitan membaca pada siswa kelas V SDI Wairotang (1) Kurangnya minat belajar siswa (2) Kurangnya dukungan keluarga dalam membaca.

Solusi yang diterapkan guru untuk mengatasi permasalahan siswa dalam kesulitan membaca pada siswa kelas V SDI Wairotang,yaitu: (1) Guru mengadakan jam tambahan bagi siswa yang masih kesulitan membaca. (2) Guru memberikan kesempatan siswa untuk membaca 15 menit setiap hari sebelum KBM dimulai. (3) Guru memberikan perhatian khusus untuk siswa yang belum lancar membaca dan masih mengeja dalam membaca.

\section{DAFTAR PUSTAKA}

Farida. R. 2011. Pengajaran Membaca Di Sekolah dasar. Jakarta: Bumi Aksara

Janurti, dkk. 2016. Analisis Kesulitan Belajar Dalam Pembelajaran Membaca Cepat Siswa Kelas V SD Gugus VI Kecamatan Abang. Jurnal OKU, Vol. 4 No. 1 Tahun 2016. 
Rizkiana. 2016. Analisis Kesulitan Membaca Permulaan Siswa Kelas I SD Negeri Bangunrejo 2 Jogjakarta. Edisi 34 tahun ke-5.

Sadli. M. 2019. Analisis Pengembangan Budaya Literasi Dalam Meningkatkan Minat Membaca Siswa Di Sekolah Dasar Muhamad Sadli. Vol. 6. No.2. p-ISNN : 2355-1925.eISSN : 2580-8915.

Pratiwi, dkk 2017. Analisis Kesulitan Siswa Dalam Membaca Permulaan Di Kelas Satu Sekolah Dasar.

Sugiyono. 2017. Metode Penelitian Pendidikan. Bandung : Alfabeta.

Sugihartono. 2007. Cara Mengatasi Kesulitan Membaca Pada Anak. Jakarta: Alfabeta

Abdurrahman, Mulyono. 2009. Pendidikan bagi anak berkesulitan belajar. Jakarta: Depdikbud \& Rineka Cipta.

Abidin, Y. 2010. Strategi membaca teori dan dan pembelajarannya. Bandung: Risqi press.

Jamaris dan Martini. 2009. Kesulitan Belajar, prespektif assesmen dan penanggulangannya. Jakarta: Yayasan Pena Mas Murni.

Moleong, Lexy. J. 2012. Metodologi Penelitian kualitatif. Jakarta: Remaja Rosdakarya.

Snowing, M. J. 2013. Early Identification and Interventions for Dyslexia: A

Tarigan, Henry, Guntur. 2018. Membaca sebagai suatu keterampilan berbahasa. Bandung: Angkasa.

Resmini dkk. 2009. Ejaan bahasa Indonesia. Bansung: Angkasa

Nuhardi. 2015. Kiat-kiat membaca. Jakarta: Alfabeta

Zuhri. 2016. Mengeja Tulisan. Bandung. Angkasa

Keraf. 1984. Cara Membaca yang Baik. Jakarta: Alfabeta 